\title{
한-아프리카 포럼 서울 선언문
}

- 2006.11.7-9간 서울에서 개최된 '제1차 한아프리카 포럼 의 참석자들은 동 포럼이 한 국과 아프리카간 우호 관계와 파트너쉽, 그 리고 협력을 증진하기 위한 틀을 마련하게 된 것을 환영한다.

- 참석자들은 오늘날 급속한 세계화 시대에서 국가간 상호의존성이 증대하는 등 급변하는 국제 환경에 대응하기 위해서는 풍부한 성장 및 개발 잠재력을 보유하고 있는 아프리카와 역동성을 지니고 있는 한국이 지역간 협력을 증진할 필요가 있다는 데 인식을 같이한다.

- 참석자들은 21 세기 국제관계의 근본적 가치 로서의 연대성(solidarity)이 가지는 중요성 을 인식하면서, 2000년 채택된 새천년개발 목표(MDGs) 이행의 중요성을 재확인하는 동 시에, 개발협력 동반자(partner)들이 아프리
카 국가들의 동 목표 달성 노력을 적극적으 로 지원해 줄 것을 촉구한다.

- 이러한 의미에서, 2006년 3월 노무현 대통령 이 아프리카 순방시 발표한 아프리카 개발을 위한 한국의 이니셔티브' 와 더불어 2008년 까지 아프리카에 대한 공적개발원조(ODA)를 3 배로 확대하는 등 원조 예산을 증액할 것이 라는 한국 정부의 발표를 높이 평가한다.

또한 향후 3 년간 1,000 명의 연수생을 초청하 는 등 아프리카 국가들의 인적자원 개발을 지 원하고 아프리카와 개발경험을 공유하겠다 는 한국 정부의 발표를 환영한다.

- 아울러 아프리카 국가들이 빈곤감소를 포함 한 '아프리카 개발을 위한 새로운 파트너쉽 (NEPAD)' 의 목표를 달성하는 데 있어 한국 
정부가 전적인 지원을 제공하겠다는 약속을 천명하였다. 또한 아프리카 국가들이 수자 원, 농업, 보건, 교육, 과학기술, 정보통신, 선 정(good governance) 등 주요분야에서 파생 하는 문제점을 해결하고자 하는 노력에 지원 을 아끼지 않겠다는 한국 정부의 약속을 환 영한다.

참석자들은 또한 이러한 협력 사업을 추진함 에 있어 한국 등 국제사회의 협력이 필요하면 서도 아프리카의 개발에 있어서는 아프리카 스스로가 주도적으로 노력해야 한다는 데 인 식을 같이한다.

- 참석자들은 한국과 아프리카간 무역 및 투자 를 증진함으로써 장기적이고 호혜적 관계를 구축할 필요가 있다고 본다.
- 참석자들은 한-아프리카 포럼이 앞으로 양 측간 긴밀한 경제적 동반자 관계 구축을 위 해서뿐만 아니라 서로 다양한 문화를 가진 사람들 간의 상호이해 증진에도 중요한 역할 을 할 것으로 보며, 상호 관심 분야에서의 보 다 긴밀한 관계 강화를 위한 의지를 재확인 한다.

- 참석자들은 '한-아프리카 포럼' 을 실질적 협 력의 메커니즘으로 발전시키기 위해 정례화 하기로 합의하였다.
대한민국, 서울 2006, 11. 8일 